\title{
The Personal Nationalism of Helmut Kohl: A paragon of Germany's new normality?
}

\author{
Christian Wicke
}

\section{Introduction}

Helmut Kohl, the purported 'Chancellor of Unity', is a key figure in the history of German nationalism. During the Cold War era, when a German nation-state was territorially absent and society in the Federal Republic of Germany (FRG) had developed a culture of Vergangenheitsbewältigung, of trying to come to terms with the horrific Nazi past, Kohl's personal nationalism made up the quest to be a normal nation. ${ }^{1}$ After World War II, the FRG assimilated into the conglomerate of Western nation-states situated under the umbrellas of NATO and the European Community. West German state officials were forced to espouse the government line that the division of the nation had been unjust and unnatural, and that the FRG was the only legitimate representative of the German nation. While West German politicians frequently faced tensions between the cultures of Vergangenheitsbewältigung and Westernisation, the representatives of the German Democratic Republic (GDR) marketed their country as the one that stood essentially in opposition to the fascist culture of the Nazi empire and its continuation in the FRG. The incorporation of the GDR into the FRG on 3 October 1990 ended this dichotomous political development in the form of the (re-)establishment of a German nation-state, which could be interpreted as a historic leap towards normality. Jürgen Habermas, who is of the same generation as Kohl, has been apprehensive about this process of normalisation. The German philosopher feared his fellow citizens would lose their critical awareness of the fact that they only truly became Western through, and after, the atrocities of the Holocaust, and were thus gambling away their post-national achievements. ${ }^{2}$

Kohl's biography provides a useful tool not only for exploring the development of contemporary nationalism in postwar Germany, but also for engaging with some theories and ideal typologies that emerged within the broad field of Nationalism Studies. This paper is not intended to offer a classic, chronological account of

1 Fischer, T. and Lorenz, M. (eds) 2007, Lexikon der 'Vergangenheitsbewältigung' in Deutschland: Debattenund Diskursgeschichte des Nationalsozialismus nach 1945, Transcript, Bielefeld.

2 Habermas, J. 1995, Die Normalität der Berliner Republik, Suhrkamp, Frankfurt am Main. 
Kohl's life, but rather to address the value of biographical method in relation to the concepts of nation and nationalism, and the application of ideal types of nationalism to the analysis of the personal nationalism of an individual. First, I shall discuss this methodological approach, and outline the (West) German context in which Kohl's personal nationalism can be located. Subsequently, I shall take some very high angle shots of four significant biographical features that together animate the 'ecology' of Kohl's national identity. ${ }^{3}$ These four features will be directly linked to particular kinds of nationalism that have been established here for analytical purposes, without assuming that this ideal typology existed in any real and pure form.

Kohl will be treated as a (1) Catholic Nationalist, whose religious denomination shaped the way he represented himself and his national identity. Kohl will then be observed as a (2) Liberal Nationalist, whose date of birth influenced his ideology and self-narration. Born on 3 April 1930, he belonged to the '45-er' generation, those who were on the whole strongly loyal to the newly Westernised state of the FRG. Further, his origin in the Rhine, in the Palatinate region near the French border, also played an important role in Kohl's personal nationalism. This allows me to examine Kohl as a (3) Romantic Nationalist, who expressed a cultural, decentralised and almost apolitical nationalism. As a final point, Kohl will be analysed as a (4) Nationalist Historian. His educational socialisation, including a PhD in History from the University of Heidelberg (in 1958) on the political reconstruction of his home region after $1945,{ }^{4}$ facilitated his world view, in which nations constitute a normative order, legitimised through the historicisation of positive continuities that transcended negative periods, such as the Nazi era. This work, moreover, had obvious autobiographical tendencies: Kohl described the place of his political socialisation.

The vanishing point of this ideal-typological analysis is Kohl's hope for normality. He saw this as only being realisable in the form of a united nationunited in ideological, cultural and (geo)political terms - which he believed he legitimised through his biography. He emphasised the four abovementioned features - denominational, generational, regional and educational - to produce an image of himself that was in accordance with his quest for the preservation, re-normalisation and thus Westernisation of German nationalism. Kohl selectively conveyed his (auto)biography in order to bring forth an image of himself that Habermas described as 'dieverkörperte Entwarnung', which can loosely be translated as 'the all-clear incarnate' or '-embodied'. Although Habermas was being slightly tongue-in-cheek when he used this expression, making an allusion to the chancellor's enormous physical size, he was primarily

3 For the concept, see Hearn, this volume.

4 Kohl, H. 1958, 'Die politische Entwicklung in der Pfalz und das Wiedererstehen der Parteien nach 1945', PhD thesis, University of Heidelberg, copied from the Bibliothek des Niedersächsischen Landtags, Hannover. 
referring to Kohl's appearance as someone whom nobody in the world should fear anymore. The Federal Republican German, as represented by Kohl, would no longer be abnormal, but finally firmly anchored in Western culture and ethics. ${ }^{5}$ The Christian Democratic politician was thus succeeding - at least to some degree - in exploiting his own biography to project his vision of Germany into the public and overcoming the Sonderweg paradigm.

\section{Nationalism, Normality and the Biographical Response}

Nationalism has become normal in the contemporary Western world, and it is not surprising that this normality has barely been problematised. In a world of nations, the historical development of nation formation is 'over the hump'. Paradoxically, however, many of our contemporaries present 'nationalism' as something extreme and outdated. Michael Billig sought to fill this notional void with his concept of 'banal nationalism', which focused on the reflexivity - or normality - of nationalism in daily life, and theorised the absence of reflectivity with regard to the mass consumption of nationalism in Western societies. ${ }^{6}$ Since the nineteenth century the nation has been imparted as an absolute norm, and questioning this norm became an immoral breach of a social taboo, as Norbert Elias pointed out. ${ }^{7}$ In 2012, Ernest Gellner's comment still seems valid for most sections of Western society: 'A man must have a nationality as he must have a nose and two ears; a deficiency in any of these particulars is not inconceivable and does from time to time occur, - but only as a result of some disaster, and it is itself a disaster of a kind. ${ }^{8}$ The congruence between sets of personal (national) identity and social (national) identity is thus usually taken for granted, instead of being analysed as a form of interaction: the individual being reduced to a homogenous rather than autonomous actor. ${ }^{9}$

This intertwining of social and individual identities is a key mechanism of nationalism and has probably greatly contributed to its phenomenal success in mass societies. In that regard, Kohl was no exception. Nationalism continues to endow people with a sense of 'being someone in the world'; ${ }^{10}$ paradoxically, both individuality and the holistic category of an anonymous collective have

5 Habermas, J. 1994, in Greiner, U. (ed.) 1994, Meine Jahre mit Helmut Kohl, Bollman, Mannheim, pp. 9-11.

6 Billig, M. 1995, Banal Nationalism, Thousand Oaks, London.

7 Elias, N. 1989, Studien über die Deutschen: Machtkämpfe und Habitusentwicklung im 19. und 20. Jahrhundert, Suhrkamp, Frankfurt am Main, pp. 194-5.

8 Gellner, E. 2006, Nations and Nationalism, [second edn], Cornell University Press, Ithaca, p. 6.

9 Hearn, this volume.

10 Geertz, C. 2000 [1973], 'The integrative revolution: primordial sentiments and politics in the new states', in C. Geertz (ed.), The Interpretation of Cultures: Selected essays, Basic Books, New York, p. 259. 
contemporaneously become zenith values; the person and nation still appear to be closely related and not as purely independent beings. The performance of one's own nation has consequently come to play a formative role in shaping modern self-esteem. ${ }^{11}$ Kohl's controversial geschichtspolitisch attempts in the 1980s to improve the German reputation in the world can be seen in this light, especially against the fact that these ambitions had already become apparent with his PhD thesis from the 1950s. For Kohl, however, like many of his West German contemporaries, 'nationalism' was a false term that was associated with Nazism and replaced with positive euphemisms (like patriotism or national consciousness). Depending on the definition of nationalism, this can lead to certain contradictions: Kohl warned, for example, of the particularistic thinking of the nineteenth century, but presented the principle of national selfdetermination as untouchable. ${ }^{12}$ Throughout his political career, moreover, he used his European-ness as evidence of his anti-nationalism, although he assured us that German unity was a self-evident aim. ${ }^{13}$ After all, being both thoroughly national and simultaneously Western was crucial to Kohl's notion of normality.

When aiming at a broad definition of nationalism, one could argue that this global mass phenomenon comprises the accumulation of all individual ideas and actions that contribute to the construction and maintenance of the nation-reflexively or purposively. The relative emptiness of the concept of nation, which stands in the centre of this definition, allows for nationalism's 'chameleon-like ability', as Anthony Smith described it, and perhaps contributes to its pertinacity. ${ }^{14}$ The extreme flexibility of nationalism in comparison with other ideologies allows for a relatively strong individualism amongst modern co-nationals within the cultural system of their nation. It is ultimately very difficult to analyse this parasitic phenomenon as a distinct ideology, as Michael Freeden pointed out. ${ }^{15}$ The notion of the nation can be charged with all kinds of ideologies, religions and historical imagination. This openness also indicates that nationalism is something fundamentally personal, as Anthony Cohen suggested. ${ }^{16}$ Co-nationalists can have very different notions of their own nation: different versions of its past, different conceptions of its present and different visions for its future. Thus, despite the shared material that each nation offers, the content depends very much on one's individual context, to some extent

11 Spinner-Halev, J. and Theiss-Morse, E. 2003, 'National identity and self-esteem', Perspectives on Politics, vol. 1, no. 3, pp. 515-32.

12 'Kohl zu CDU-Jugend: nationalistische Politik undenkbar', Westdeutsche Allgemeine Zeitung, 26 September 1970.

13 'Dr. Helmut Kohl neuer Regierungschef', Staats-Zeitung, 25 May 1969.

14 Smith, A. 1991, National Identity, University of Nevada Press, Reno, p. 144.

15 Freeden, M. 1998, 'Is nationalism a distinct ideology?', Political Studies, vol. 46, no. 4, pp. 748-65.

16 Cohen, A. 1996, 'Personal nationalism: a Scottish view of some rites, rights and wrongs', American Ethnologist, vol. 23, no. 4, pp. 802-15, at pp. 803-5; Cohen, A. 1996, 'Owning the nation, and the personal nature of nationalism: locality and rhetoric of nationhood in Scotland', in V. Amit-Talai and C. Knowles (eds), Re-situating Identities: The politics of race, Ethnicity, Culture, Broadview, Peterborough, Ontario, p. 280. 
contingent on features such as one's date of birth, locality, family background, education, political affiliation, and so on. On top of (and in stark correlation to) these categorisable biographical features, very personal experiences can play an important role in the making of imaginations and representations of nationhood: Kohl's experiences of loss and gain during World War II and its aftermath were both generational and personal, and endowed his representation of self and nationhood with central impressions and narratives. ${ }^{17}$

That is exactly where the method of biography offers fresh perspectives on the study of nationalism. A biographical approach to nationalism can illuminate the nationalist's 'ideas in context': how are individual ideas shaped by the personal context, and how does the protagonist seek to manipulate the status quo ${ }^{18}$ From this point of view, one can go further than Cohen suggested with his concept of personal nationalism: personal nationalism is not only the individual identification with the nation, or a form of self-imaging, it is also the specific ideological and biographical constellation within the personal notion of one's nation-deriving from the individual's socialisation. It is thus strongly context dependent, with the contexts varying and overlapping at the personal level. It is the mix of different sociological categories that surrounds the individual combined with the 'non-categorisable' that make biography a very attractive method. In the case of Kohl, this method demonstrates the individual roots and representation of a firm ideological position within the discursive competition over the meaning of German nationhood.

\footnotetext{
17 Kohl's first major autobiographical work focused on his role during the unification process; see Kohl, H. 1996, Ich wollte Deutschlands Einheit, K. Diekmann and R. Reuth (eds), Propyläen, Berlin; see also Kohl, H. 2000, Mein Tagebuch: 1998-2000, Droemer, Munich, which he wrote in response to the CDU contributions scandal of 1999. For Kohl's most important autobiographical writing, see the three volumes of his memoirs: Kohl, H. 2004, Erinnerungen 1930-1982. Volume I, Droemer, Munich; Kohl, H. 2005, Erinnerungen 1982-1990. Volume II, Droemer, Munich; Kohl, H. 2007, Erinnerungen 1990-1994. Volume III, Droemer, Munich. Kohl has recently published a shorter version of his memories of the reunification process in order to reach a broader readership; see Kohl, H. 2009, Vom Mauerfall zur Wiedervereinigung: Meine Erinnerungen, Droemer, Munich. 18 For Quentin Skinner's 'ideas in context' approach, see Tully, J. (ed.) 1988, Meaning and Context: Quentin Skinner and his critics, Polity, Cambridge; Bock, B., Skinner, Q. and Viroli, M. 1990, Machiavelli and Republicanism: Ideas in context, Cambridge University Press, Cambridge; Skinner, Q. 2000, Machiavelli: A very short introduction, Oxford University Press, Oxford; Skinner, Q. 2002, Visions of Politics. Volume I, Cambridge University Press, New York. See also Ashcraft, R. 1986, Revolutionary Politics and Locke's Two Treatises of Government, Princeton University Press, Princeton, NJ; Ashcraft, R. 1971, 'Hobbes's natural man: a study in ideology formation', The Journal of Politics, vol. 33, pp. 1076-117.
} 


\section{German Nationalism and the Quest for Normality}

After the downfall of the Third Reich, German politicians sought to extract 'good and normal patriotism' from 'bad and abnormal nationalism' ${ }^{19}$ Normality was about the reconstruction of the country, the need for security, the suppression and denial of the Nazi past, and about the question of the divided nation-state. Further, the concept of normality related to the belief that the German nation and its history were special in psychological, social, cultural and political terms. Before 1945, the perception that Germans were different to other nations was viewed as positive; afterwards it was reversed into something negative: normality was about being like all other peoples in the West. ${ }^{20}$

The first West German Chancellor, Konrad Adenauer, a Catholic Rhinelander from the Christian Democratic Union (CDU), laid the foundation for the partial normality in the 1950s that Kohl later felt obliged to defend: Adenauer stood for unconditional integration with the West or Westbindung. ${ }^{21}$ Since the 1960s, however, when Fritz Fischer caused a long-lasting furore by arguing that Germans had followed a negative historical trajectory from the Protestant Reformation towards Nazism, and that their imperialist attitude had triggered World War I, the unity of German historiography has been publicly contested. ${ }^{22}$ The Nazi episode would subsequently be historicised as more than simply a historical accident that might also have occurred in other nations; rather it was depicted as the cumulative result of peculiarly German developments: Germany's un-Western Sonderweg, or special path. At the same time, Adolf Eichmann's sentencing in Jerusalem and a series of Auschwitz trials in Frankfurt increasingly confronted the public with the German past, which then appeared as anything but normal. ${ }^{23}$ Consequently, conservatives, including the young Kohl, publicly agitated against the initial calls for younger generations to recognise the crimes committed in Nazi Germany. ${ }^{24}$

19 Gabbe, J. 1976, Parteien und Nation: Zur Rolle des Nationalbewußtseins für die politischen Grundorientierungen der Parteien in der Anfangsphase der Bundesrepublik, Anton Hain, Meisenheim.

20 See Aleida Assmann on the notion of normality in (West) Germany: Assman, A. 1999, 'Die Schlagworte der Debatte', in A. Assmann and U. Frevert, Geschichtsvergessenheit, Geschichtsversessenheit: Vom Umgang mit deutschen Vergangenheiten nach 1945, DVA, Stuttgart, pp. 59-63; see also Niethammer, L. 2001, " Normalization" in the West: traces of memory leading back into the 1950s', in H. Schissler (ed.), The Miracle Years: A cultural history of West Germany, 1949-1968, Princeton University Press, Princeton, NJ, Ch. 10.

21 Poppinga, A. 1975, Konrad Adenauer: Geschichtsverständnis, Weltanschauung und politische Praxis, DVA, Stuttgart; Frei, N. 2002, Adenauer's Germany and the Nazi Past: The politics of amnesty and integration, J. Golb (trans.), Columbia University Press, New York.

22 Moses, J. 1975, The Politics of Illusion: The Fischer controversy in German historiography, Prior, London.

23 Wittmann, R. 2005, Beyond Justice: The Auschwitz trial, Harvard University Press, Cambridge, Mass.

24 Fröhlich, C. 2005, Wider die Tabuisierung des Ungehorsams: Fritz Bauers Widerstandsbegriff und die Aufarbeitung von NS-Verbrechen, Campus, Frankfurt am Main, pp. 151-2; Bauer, F. 1961, Die Wurzeln faschistischen und nationalsozialistischen Handelns, Landesjugendring Rheinland-Pfalz, Mainz. 
By the end of the 1960s, university students were at the forefront of the movement that was challenging the normality of their young country and their silent parents, whom they held responsible for Auschwitz. ${ }^{25}$ The year 1968 stood for another normalisation of Germany, a different kind of Westernisation, different to what Kohl had in mind. The '68-ers' deconstructed the myth of the Stunde Null (the zero hour of 1945), thus exposing the continuities between Nazism and Federal Republicanism. The Social Democrat Willy Brandt, who became chancellor in 1969, responded to the rising demands for greater Vergangenheitsbewältigung (coming to terms with the past), which was not appreciated by the majority of the West German mainstream. ${ }^{26}$ Normality was still open to dispute. The Christian Democrats, including Kohl, agitated against Brandt's new foreign policies towards the East, in which they saw the betrayal of the constitutional demand for unification. ${ }^{27}$

The change in the political climate in the mid 1970s, moreover, quickly ignited a reactionary spirit that yearned for the lost values of the 1950s, which Kohl sought to reactivate. ${ }^{28} \mathrm{Kohl}$, as Chairman of the CDU from 1973 onwards, sought to repair the damage caused by the post-national 68-ers, and marketed his coming to power in 1982 as a geistig-moralische Wende (spiritual moral change). ${ }^{29}$ While the division of Germany itself increasingly became accepted as normal, Kohl sought to endow the citizenry with a national identity. This, he felt, was needed to pre-empt the normalisation of a post-national identity, as envisaged by the philosopher and major public intellectual Habermas and his left-liberal associates. ${ }^{30}$ It was this tension that led to the Historikerstreit (the German history wars) in 1986, which would have been hard to conceptualise without the conservative reaction headed by Kohl's government. ${ }^{31}$ In the 1980s, there was a growing desire to dismantle the German stigma, shaking off the burden, rejecting the notion that the nation's division had been a punishment for the uniquely evil crimes the Germans had committed. ${ }^{32}$ Kohl responded to

25 Kundnani, H. 2009, Utopia or Auschwitz: Germany's 1968 generation and the Holocaust, Columbia University Press, New York.

26 Fink, C. and Schaefer, B. (eds) 2009, Ostpolitik, 1969-1974: European and global responses, Cambridge University Press, Cambridge; 'Kniefall angemessen oder übertrieben?', Der Spiegel, 14 December 1970.

27 Clemens, C. 1989, Reluctant Realists: The Christian Democrats and West German Ostpolitik, Duke University Press, Durham, NC.

28 'Tendenzwende: Jeder fühlt den neuen Wind', Der Spiegel, 6 January 1975.

29 Seuthe, R. 2001, Geistig-moralischen Wende?: Der politische Umgang mit der NS-Vergangenheit in der Ära Kohl am Beispiel von Gedenktagen, Museums-und Denkmalprojekten, Peter Lang, Frankfurt.

30 Habermas, J. 1988, 'Historical consciousness and post-traditional identity: remarks on the Federal Republic's orientation to the West', Acta Sociologica, vol. 31, no. 1, pp. 3-13.

31 Maier, C. 1988, The Unmasterable Past: History, Holocaust, and German national identity, Harvard University Press, Cambridge, Mass.

32 Moses, A. 2007, German Intellectuals and the Nazi Past, Cambridge University Press, Cambridge, pp. $24-31,258$. 
this desire and sought to amplify it. His search for normality was about both the departure from the old, anti-Western Sonderweg and the closure of the new, post-national Sonderweg. ${ }^{33}$

The question of whether Germany as a nation had undergone an abnormal historical trajectory outside the West has become one of the most important historiographical questions of the postwar era. ${ }^{34}$ This question concerns a kind of normality that is about the memory of two world wars and the Holocaust, and not primarily the absence of the nation-state in the context of the Cold War, although the latter has sometimes been historicised as the result of the former. Because of the Federal Republican society's Westernisation during the Cold War era, one could argue that Germans came closer to an international status of normality. This process of normalisation, which Kohl's chancellorship aimed to foster, neared its completion through Germany's sudden (re)unification within a Western framework. This merger of East and West Germany in 1990 was a prime example of a nationalist event, confirming the globally idealised congruency of state and nation, and has thus been described as Germany's return to normality. ${ }^{35}$ During the (re)unification process, however, Kohl anticipated an ongoing struggle for normality in the post-unification era. Kohl pleaded 'that things will normalize...that we become a wholly normal country, not "singularized" in any question...that we simply don't stick out' ${ }^{36}$ Yet, against the backdrop of

33 Berger, S. 2007, The Search for Normality. National identity and historical consciousness since 1900, [revised edn], Berghahn, Oxford, pp. xiii-xxvi, 176-97.

34 There are different interpretations of the Sonderweg thesis; a comprehensive review is outside the scope of this paper. For a concise introduction to the controversial concept of the Sonderweg, see Kocka, J. 1988, 'German history before Hitler: the debate about the German "Sonderweg"', Journal of Contemporary History, vol. 23, no. 1, pp. 3-16. For this paper, it makes little sense to distinguish between Sonderweg and Sonderbewußtsein (special mentality), as Karl D. Bracher suggested. For this discussion, see Bracher, K. (ed.) 1982, Deutscher Sonderweg: Mythos oder Realität?, Institut für Zeitgeschichte, Munich, p. 53. For the notion of a cultural Sonderweg, see Watson, P. 2010, The German Genius: Europe's third renaissance, the second scientific revolution and the twentieth century, Harper Collins, New York, p. $28 \mathrm{ff}$. Important scholars on nationalism have reinforced the conception of a cultural Sonderweg in Germany, in which romanticism had a negative function in the course towards Nazism. See, in particular, Kohn, H. 1994, The Idea of Nationalism: A study of its origin and background, Macmillan, New York; and Greenfeld, L. 1992, Nationalism: Five roads to modernity, Harvard University Press, Cambridge, Mass., pp. 10-11. For early cultural Sonderweg explanations of Nazism, see, for example, Stern, F. 1961, The Politics of Cultural Despair: A study in the rise of the Germanic ideology, University of California Press, Berkeley; Viereck, P. 2004, Metapolitics: From Wagner and the German romantics to Hitler, [expanded edn], Transaction Publishers, New Brunswick; and Shirer, W. 1962, The Rise and Fall of the Third Reich: A history of Nazi Germany, Secker \& Warburg, London.

35 Habermas, J. 1995, Die Normalität einer Berliner Republik, Suhrkamp, Frankfurt am Main, p. 170. For a recent discussion on the concept of normality in the German context, see Taberner, S. and Cooke, P. (eds) 2006, German Culture, Politics and Literature into the Twenty-First Century: Beyond normalization, Camden House, Columbia, SC; Breuilly, J. and Speirs, R. 2005, 'The concept of unification', in J. Breuilly and R. Speirs (eds), Germany's Two Unifications: Anticipations, experiences, responses, Palgrave Macmillan, Basingstoke, UK, p. 2. 36 Schmemann, S. 1990, 'Kohl, the man for the German movement', The New York Times, 1 July 1990. 
the remaining memory of Nazism, combined with the celebration of Germany's national re-creation, it remains debatable whether German society can even now be considered as a normal nation. ${ }^{37}$

\section{Kohl as Catholic Nationalist}

Catholicism played an important role throughout Kohl's life and in his rhetoric. Kohl explicitly stated that his motivation for joining the Christian Democrats in 1946 was 'the black [that is, Catholic] milieu from which I originate' ${ }^{38}$ His political party would become the most significant social organisation in Kohl's life and provide a solid platform from which to express his Federal Republican nationalism. After World War II, his political mentor, the local priest Father Finck, introduced him to the principles of Christian democracy, and facilitated his CDU membership at the remarkably young age of sixteen. Kohl saw in his mentor's authorisation of de-Nazification certificates how Nazis were rehabilitated in an act of Christian fairness. ${ }^{39}$ Finck embodied to Kohl the epitome of the unsuspicious Catholic tradition in German nationalism-and the moral obligation to fight for the unity of the nation. At that time he learned about Catholic social teaching and the importance of Christianity for the new German state, which should represent the good essence of the nation. ${ }^{40}$ The atheist failures of Nazism were taught as being equally prevalent in socialist materialism, with the East threatening the Occidental culture. ${ }^{41}$ The long and painful hangover from the Kulturkampf (1871-78), which Otto von Bismarck had launched against German Catholicism in the newly established nation-state under the hegemony of Lutheran Prussia, finally came to an end in 1949 with the establishment of the Federal Republic of Germany and the CDU as its major conservative force. The Protestant centre in Germany was then sidelined to the GDR and the former Reichsfeinde [the enemies of the state] turned their exclusion from power in Berlin into a virtue, allowing them to reject both

\footnotetext{
37 Bleek, W. and Maull, H. (eds) 1989, Ein ganz normaler Staat? Perspektiven nach 40 Jahren Bundesrepublik, Piper, Munich. Habermas feared the national normalisation of Germany; see Habermas, J. 1992, 'Die zweite Lebenslüge der Bundesrepublik: Wir sind wieder "normal" geworden', Die Zeit, 11 December 1992. On the other hand, Germans from the centre-right and the centre-left were careful to not do things fundamentally differently than in the West; see Winkler, H. 2001, 'Ende Aller Sonderwege', Der Spiegel, 11 June 2001, $<$ http://www.spiegel.de/spiegel/print/d-19383801.html> The Walser-Bubis debate symbolised the ongoing controversy about the question of whether Germans and their memory culture should become normal; see Schirrmacher, F. 2010, Die Walser-Bubis Debatte, Suhrkamp, Frankfurt/Berlin.

38 Kohl, Erinnerungen 1930-1982, p. 57.

39 Schwarzmüller, T. 2002, Albert Finck und die Nationalhymne: Eine Lebensreise vom Kaisserreich zur Bundesrepublik, Plöger, Annweiler, p. 88.

40 Kohl, Erinnerungen 1930-1982, pp. 72-3; Victor, C. 1906, Sozialismus: eine Untersuchung seiner Grundlagen und seiner Durchführbarkeit, Herdersche, Freiburg im Breisgau. Kohl, Die politische Entwicklung in der Pfalz und das Wiedererstehen der Parteien nach 1945, Ch. IV.

41 See also Mitchell, M. 1995, 'Materialism and secularism: CDU politicians and national socialism, 19451949', Journal of Modern History, vol. 67, no. 2, pp. 278-308.
} 
Prussian militarism and its National Socialist stepchild', as Ronald Granieri put it. ${ }^{42}$ The problematic relationship between the Vatican and the Nazis was concealed. Adenauer, the former mayor of Cologne, became the first Federal Republican chancellor, and, for Kohl, Germany's most important national hero. Adenauer personified the alternative to the Sonderweg and used Catholic maxims to reform German conservatism. ${ }^{43}$ Under the new chancellor, the policy of Western integration was presented as the salvation of the Christian Occident against the communist threat. ${ }^{44}$ The new party represented what young Kohl had already learned at Finck's political Sunday school, although with a greater emphasis upon capitalism. ${ }^{45}$ Kohl wrote about the mind-set of his Palatine educators in his doctoral dissertation, ${ }^{46}$ and there is no evidence that Kohl's ideology fundamentally changed from this point in his life, from the age of twenty-eight. In 1991, when the Cold War was finally over, he proclaimed at the Katholikentag: 'today we can assert that Marx erred in his prediction that the days of religion were numbered. It all happened differently. Under communist dictatorship the people realised that Marxism does not have an answer to the meaning of life.' ${ }^{47}$

Kohl has constantly exposed his Catholic identity: he wrote about his Catholic upbringing and his friendship with clerics, and he enjoyed the public images of his relatively frequent meetings with the popes over the decades (with the last meeting in 2011). ${ }^{48}$ His personal nationalism has been reminiscent of Pope John Paul II's Memory and Identity, in which nationalism is presented as a Christian command. ${ }^{49}$ 'As a Pole', Kohl explained in 1980, Pope John Paul knew 'what it means when the Heimat is violently cut up'. ${ }^{50}$ In articles and in his memoirs,

42 Granieri, R. 2004, 'Thou shalt consider thyself a European: Catholic supranationalism and the sublimation of German nationalism after 1945', in M. Lehmann and H. Lehmann (eds), Religion und Nation, Nation und Religion: Beiträge zu einer unbewältigten Geschichte, Wallstein, Göttingen, p. 340.

43 Williams, C. 2000, Adenauer: The father of the new Germany, Little, Brown \& Company, London, p. 221.

44 Herf, J. 1993, 'Multiple restorations: German political traditions and the interpretation of Nazism, 19451946', Central European History, vol. 26, no. 1, pp. 21-55, at pp. 40-2.

45 See Uertz, R. 1981, Christentum und Sozialismus in der frühen CDU: Grundlagen und Wirkungen der christlich-sozialen Ideen in der Union, 1945-1949, DVA, Stuttgart; Spicka, M. E. 2007, Selling the Economic Miracle: Economic reconstruction and politics in West Germany, 1947-1957, Berghahn, Oxford, p. 18; Pridham, G. 1977, Christian Democracy in Western Germany: The CDU/CSU in government and opposition, 1945-1976, Croom, London, pp. 21-34.

46 Kohl, Die politische Entwicklung in der Pfalz und das Wiedererstehen der Parteien nach 1945, Ch. IV.

47 Kohl, H. 1993, 'Christen in Verantwortung für Europa', [Speech delivered at the 57th Katholikentag, Johanniskreuz, 23 June 1991], in P. Hintze and G. Langguth (eds), Helmut Kohl: Der Kurs Der CDU, Reden und Beiträge des Bundesvorsitzenden 1973-1993, DVA, Stuttgart, p. 367.

48 You are here Kohl, H. 1993, 'Unabhängig aber partnerschaftlich kooperieren', [Interview with the Herder Korrespondenz, March 1975], in ibid., p. 105; Kohl, Erinnerungen 1930-1982, vol I, Droemer, Munich, p. 54, 140-1, 495-6, 516-7; Kohl, Erinnerungen 1990-1994, p. 991; Ramstetter, E. 2005, 'Die christlichen Wurzeln des Politikers Helmut Kohl', Politische Meinung, vol. 424, Konrad-Adenauer-Foundation, <http://www.kas. de/wf/doc/kas_6327-544-1-30.pdf?07092512214>

49 John Paul II, 2005, Memory and Identity: Personal reflections, Weidenfeld \& Nicolson, London.

50 Kohl H. 1980, Ehrung der ganzen deutschen Nation, [article on the visit of John Paul II], DeutschlandUnion-Dienst 34:213, [Press release], 10 November 1980, Archive of the Konrad-Adenauer-Foundation, Kohl/ Artikel. 
Kohl described his childhood as religious and patriotic, and his parents' faith as an indication of their guiltlessness during the Nazi era without failing to love their fatherland. ${ }^{51}$ The Catholic symbols of his home region were to Kohl simultaneously German and European lieux de mémoire: 'especially the Cathedral of Speyer, built in the eleventh century as the greatest church in the occident [which was for him] a symbol of unity of the German and European history' ${ }^{52}$ Kohl wrote that 'the Roman-German Kaisers' who once resided in this region 'did not rule over a nation-state, but over an early house of Europe, which reached from Sicily to the North Sea. They contained the consciousness of the occidental world in themselves, this ancient and Christian Kulturkreis. ${ }^{.53}$

His Catholic background endowed Kohl with a powerful source to mobilise an image of an innocent, Western German. Similar to Adenauer, for Kohl, this biographical feature allowed him to articulate a notion of Germany that stood in contrast with the allegedly dangerous Prussian-Lutheran representation of Germany that was associated with the abnormal Sonderweg. Kohl was able to present a narrative of himself that was aligned with the Federal Republican narrative of the German nation, as one that was not essentially supportive or characteristic of Nazism. To speak with the words of Jonathan Hearn, Kohl could thus portray himself as "moving/acting "with the flow" of an encompassing historical narrative' of the new FRG and as one who is 'moving/ acting "against the flow" of an encompassing historical narrative' of Nazism, which would become increasingly unpopular. ${ }^{54}$ The proto-religious tendencies of nationalism are not a new insight. Since the 1920s, beginning with Carleton Hayes, nationalism has often been portrayed as ersatz religion - a substitute for religion that itself has religious features. ${ }^{55}$ When looking at Kohl's rhetoric, however, what is much more interesting is that he used religious content to fill his notion of the German nation. Or, to use another of Hearn's metaphors, Kohl's nationalism was 'embedded' in the social-identity category of Catholicism. ${ }^{56}$ Kohl's Catholicism underlay all the other ideological pillars that sustained his personal nationalism - in particular, the way he interpreted liberal principles, but also the way he romanticised the homeland and the way he historicised its past. In all regards, his Catholicism helped Kohl to represent a benign nationalism, bound to the West.

\footnotetext{
51 Kohl, H. 1984, 'Katholisch, liberal, patriotisch', in R. Pörtner (ed.), Mein Elternhaus: Ein Deutsches Familienalbum, Econ, Düsseldorf; Kohl, H. 1987, 'Kohl über die Gnade der späten Geburt', Welt am Sonntag, 1 November 1987; Kohl, Erinnerungen 1930-1982.

52 Kohl, Erinnerungen 1930-1982, p. 25.

53 Kohl, Erinnerungen 1930-1982, p. 26.

54 See Hearn, this volume.

55 Hayes, C. 1926, Essays on Nationalism, Macmillan, New York, p. 104.

56 Hearn, this volume.
} 


\section{Kohl as Liberal Nationalist}

Kohl can also be studied as a liberal nationalist, as defined by Yael Tamir and David Miller. These two theorists synthesised liberalism and nationalism after the fall of communism, based on the assumption that functioning liberal democracies had been proven to be reliant on nationalist ideals that merely required the taming force of liberalism. ${ }^{57}$ This aspect was most fundamental to Kohl's demonstration of a benign, trustful, Western nationalism during his quest to correct its old, illiberal and new, post-national Sonderweg. Similar to his religious upbringing, Kohl's generational belonging endowed him with a powerful source to articulate an authentic image of German normality and the new liberalism that developed after World War II. Born in 1930, Kohl belonged to the '45 generation'. Dirk Moses explained that, having experienced the failure of the Nazi ideology, Kohl's generation developed a 'republican consensus', which they later felt was threatened by the ' 68 generation' ${ }^{58}$ Kohl represented the liberal-conservative camp of his generation, a form of Federal Republicanism that was qualified by a liberal nationalism, aiming at the sublimation of nationalist traditions and not at their abortion. Unlike the constitutional patriotism of his coeval Habermas, Kohl portrayed West Germany's Constitution as the most precious national symbol, based on German traditions. ${ }^{59}$

In order to represent normality, Kohl could resort to a personal and generational narrative of the Third Reich and World War II: too young to be guilty, but old enough to see what happened - and in a position to learn from his own national history. This is what Kohl tried to suggest with his contentious slogan of 'grace of late birth' at the Knesset in $1984 .{ }^{60}$ On the whole, however, this narrative has been repetitively publicised by his biographers and himself, which helped him to sustain the image of an innocent German who was longing for peace and

57 Tamir, Y. 1993, Liberal Nationalism, Princeton University Press, Princeton, NJ; Miller, D. 1995, On Nationality, Clarendon Press, Oxford.

58 A. Dirk Moses, German Intellectuals and the Nazi, Cambridge University Press, Cambridge.

59 Habermas, J. 1986, 'Eine Art Schadensabwicklung', Die Zeit, 11 July; Habermas, J. 1992, 'Staatsbürgerschaft und nationale Identität', in J. Habermas, Faktizität und Geltung, Suhrkamp, Frankfurt am Main; Kohl, H. 1973, Verfassung und Nation als Auftrag der Unionspolitik, Speech delivered to the Catholic Academy in Munich, Uncorrected ms, 8 December 1973, Archive of the Konrad Adenauer Foundation, Kohl/Reden; Kohl, H. 1974, Das Grundgesetz - Verfassung der Freiheit, Speech delivered at the Frankfurter Paulskirche, Uncorrected ms, 23 May 1974, Archive of the Konrad Adenauer Foundation, Kohl/Reden; Kohl, H. 1984, 'Die Bedeutung von Heimat und Gemeinde für die demokratische Verfassungsordung', [Speech delivered on the 700th anniversary of the city of Haltern, 8 February 1984], BPA Bulletin, vol. 13, p. 125.

60 The notion of Gnade der späten Geburt was developed by Günter Gaus and initially had a different meaning; see 'Verschwiegene Enteignung: Wer erfand die Wendung von der "Gnade der späten Geburt"?', Der Spiegel, 15 September 1986; Kohl, H. 1984, 'Besuch in der Knesset', BPA Bulletin, vol. 13, 25 January 1984 , p. 112. Kohl used the concept of 'grace of late birth' a long time before he caused this controversy; see Harpprecht, K. 1970, 'Klaus Harprecht im Gespräch mit Dr. Helmut Kohl, Ministerpräsident von RheinlandPfalz', [Interview with Helmut Kohl, ZDF Dialog], BPA press review, 23 April 1970. 
freedom: ${ }^{61}$ Kohl had experienced bombing as a child, his father had gone to war, and his brother fell. The boy sat in bunkers and collected dead bodies. When he turned fifteen, he was transferred from a Hitler Youth camp to protect Hitler's Eagle's Nest. A few days later, the area was bombed and Kohl began to walk back home to Ludwigshafen. This chaotic return in 1945, which took several weeks, ultimately symbolises the beginning of Kohl's search for normality. Kohl was subsequently able to present himself as a guiltless witness of the transition from the Third Reich to Adenauer's Bonn Republic, which he perceived as a positive and existential movement towards normality. He became politically active and established himself quite successfully within this atmosphere of restoration and renewal, but also insecurity. He witnessed the economic miracle, the Westernisation of the West German mainstream and the rehabilitation of the new state within the transatlantic and Western European frameworks. Adenauer's doctrine of Western integration became the superior rationale in Kohl's conceptions of society, state and nation. Kohl was convinced that through this movement under Adenauer 'we achieved the cutback of disputable German traditions, namely the anti-Western effects of nationalism' ${ }^{62}$ His constant defence of Adenauer's legacy, of taming German nationalism under the primacy of 'freedom', which then meant 'the West', facilitated Kohl's appearance as the paragon of German normality, while he tried to stimulate a national revival. ${ }^{63}$

Kohl's aim was to conflate national and Western identities in Germany. In his world view, West Germans had already found their natural state in the liberal system of the Federal Republic, whereas East Germans had not. ${ }^{64}$ Therefore, normality was incomplete. Like Ernest Renan, he theorised the nation as based on the willingness to be a nation and simultaneously claimed that all Germans wanted to share one nation-state. ${ }^{65}$ In keeping with the liberal-nationalist tradition, the common 'will' of the people was, for Kohl, decisive in the formation of a nation: 'the awareness of common history, common ancestry, finds a specific component in the desire for common political action', as he wrote in $1973 .{ }^{66}$ 'Since the French Revolution', Kohl argued, also at the Catholic Academy in Munich, 'the notion of nation has not been detachable from the notion of

61 Many biographies on Kohl have appeared over the decades. For some in-depth biographical accounts, though predominantly in line with Kohl's autobiographical presentation of his youth, see Dreher, K. 1998, Helmut Kohl: Leben mit Macht, DVA, Stuttgart; Filmer, W. and Schwan, H. (eds) 1990, Helmut Kohl, [fourth edn], ECON, Düsseldorf, p. 29. For the most recent biography, see Hans-Peter Schwarz's 1000-page volume: Helmut Kohl: Eine politische Biographie, DVA, Stuttgart.

62 Kohl, H. 1973, Zwischen Ideologie und Pragmatismus, A. Rummel (ed.), Bonn Aktuell, Stuttgart, p. 62.

63 See, for example, Kohl, Verfassung und Nation als Auftrag der Unionspolitik.

64 Kohl, Zwischen Ideologie und Pragmatismus, p. 45; Kohl, H. 1993, 'Europa und die deutsche Frage', Lutherische Monatshefte, May 1981, Reprinted in Hintze and Langguth, Helmut Kohl, pp. 200-1.

65 Renan, E. 2009 [1882], 'Qu'est ce qu'une nation?', [Speech delivered at Sorbonne University, Paris], Discours et Conférences, BiblioLife, Charleston, SC.

66 Kohl, H. 1973, Zwischen Ideologie und Pragmatismus: Aspekte und Ansichten zu Grundfragen der Politik, A. Rummel (ed.), Bonn Aktuell, Stuttgart, p. 46. 
state'; ${ }^{67}$ however, the 'central content of German political consciousness' was, according to him, 'not the nation-state, but the liberal political order' ${ }^{68}$ As a liberal-nationalist, Kohl thus found an instrumental way to present the nation as an a-priori fact, willed by all Germans, without failing to guarantee the good, liberal, Western nature of his nationalism as representative of his entire nation. According to Kohl:

[O] ur consciousness of state and nation are identical, because we connect the willingness to national unity with the willingness for a very specific form of state, that is the liberal as opposed to the illiberal. According to the historical development of the Anglo-Saxon countries are the values of our national consciousness most closely connected to the basic democratic values. ${ }^{69}$

\section{Kohl as Romantic Nationalist}

It is also possible to look at Kohl as a romantic nationalist, as someone who regarded culture and ethnicity - and not the state - as the essence of a nation. This kind of nationalism reappeared in Germany in reaction to the repetitive absence of the nation-state. A very interesting paper on romantic nationalism was given more than 20 years ago in Canberra by the conservative German historian Thomas Nipperdey. ${ }^{70}$ Nipperdey was reacting against the often-held mistrust of this type of nationalism, which developed most strongly in German lands after the French Revolution and which was usually held to be illiberal and bad, as opposed to an allegedly good and liberal nationalism associated with the West. John Hutchinson's work on cultural nationalism is very similar to Nipperdey's positive approach to romantic nationalism. ${ }^{71}$ If one looks at other popular writing in the field of nationalism, however - for example, at Hans Kohn's or Liah Greenfeld's work - it is noticeable that German romanticism has been used to sustain the cultural Sonderweg thesis. ${ }^{72}$

67 Kohl, Verfassung und Nation als Auftrag der Unionspolitik, p. 63; Kohl, Zwischen Ideologie und Pragmatismus, p. 46. Relevant sections in Kohl's book Zwischen Ideologie und Pragmatismus are almost identical with his speech at the Catholic University in December 1973. Also, Kohl's speech on national identity in the Federal Republic at the Political Seminar of Bad Godesberg resembled large sections of his book; see Kohl, H. 1973, Deutsche Nation-Bundesrepublik Deutschland, Speech delivered at Politisches Seminar, Bad Godesberg, Uncorrected ms, 23 January 1973, Archive of the Konrad-Adenauer-Foundation, Kohl/Reden.

68 Kohl, Zwischen Ideologie und Pragmatismus, p. 56.

69 This section of Kohl's book Zwischen Ideologie und Pragmatismus is identical to Kohl's speech, Verfassung und Nation als Auftrag der Unionspolitik, p. 64.

70 Nipperdey, T. 1983, 'In search of identity', in J. C. Eade (ed.), Romantic Nationalism in Europe, ANU Press, Canberra.

71 Hutchinson, J. 1999, 'Re-interpreting cultural nationalism', Australian Journal of Politics and History, vol. 45, no. 3, pp. 392-409; Hutchinson, J. 2005, Nations as Zones of Conflict, Thousand Oaks, London.

72 Kohn, H. 1944, The Idea of Nationalism: A study of its origin and background, Macmillan, New York; Greenfeld, Nationalism. 
While being transformed through the shock of 1945, ethnic and cultural notions of German nationhood once more became a kind of compensatory nationalism in response to the territorial constraints of the Cold War era. ${ }^{73}$ In fact, the structural restrictions - the loss of territory in the East, the division of the nation and the West German Constitution, and to some extent also European integrationstrengthened a romantic imagination of local, national and supranational cultures as constitutive of the German Volk. Kohl could thus represent a romantic nationalism that was reconciled with-and ultimately subordinated to-his liberal nationalism. The most dominant aspect of his romantic nationalism was his continuous propagation of Heimat $^{74}$ as an apolitical identity of destiny, a cultural notion of homeland that would not explicitly refer to the nationstate. Kohl stressed his regional identity to represent a typical German national, naturally rooted in lovable local traditions of a culturally decentralised people, and foremost Western. This ideological and biographical feature had already surfaced clearly in his $\mathrm{PhD}$ thesis, in which Kohl sought to impart a stereotype of the liberal, non-dogmatic, tolerant, cheerful, wine-drinking, down-to-earth, spirited, cosmopolitan and Francophile Pfälzer from the Rhine. ${ }^{75}$ And also later, during his political heyday, he aimed at the representation of a typically Palatine habitus. He spoke publicly with a thick local dialect, brought foreign statesmen to Speyer Cathedral and Hambach Castle, and took them to his local restaurant for his favourite dish, Saumagen. ${ }^{76}$

Celia Applegate used Kohl's home region as a case study to learn more about the general idea of Heimat in Germany. ${ }^{77}$ Heimat appeared during the conservative reaction to 1968 as less burdened than the terms 'nation', 'Volk' or 'Fatherland',78 however, like nation, notions of Heimat can differ greatly, and it would be wrong to assume that the concept of Heimat was restricted to conservative or rightwing discourses. The best counter-example vis-a-vis Kohl is represented by the Marxist Philosopher Ernst Bloch, who was, like Kohl, from Ludwigshafen, and who saw in Heimat something that people hoped for, something to be realised in the future, in a real democracy, in absence of the workers' exploitation. ${ }^{79} \mathrm{Kohl}$ 's Heimat ideology, in contrast, sought to mediate between a romanticised German

\footnotetext{
73 See Otto Dann, O. 1995, 'Nationale Fragen in Deutschland: Kulturnation, Volksnation, Reichsnation', in E. Francois et al (eds), Nation und Emotion, Vandenhoek \& Ruprecht, Göttingen, pp. 66-82.

74 For the concept of Heimat, see, for example, Popper, K. 1927, 'Zur Philosophie des Heimatgedankens', Die Quelle, vol. 77, no. 10, pp. 899-908; Applegate, C. 1990, A Nation of Provincials: The German idea of Heimat, University of California Press, Berkeley; Blickle, P. 2004, Heimat: A critical theory of the German idea of homeland, Camden House, Columbia; Umbach, M. and Huppauf, B. 2005, Vernacular Modernism. Heimat, globalization, and the built environment, University of Stanford Press, Stanford, Calif.

75 Kohl, Die politische Entwicklung in der Pfalz und das Wiedererstehen der Parteien nach 1945, pp. 48, 160.

76 Crolly H. 2010, 'Pfalz: “Deidesheimer Hof": Kohls zweites Wohnzimmer', Die Welt, 4 April 2010, <http:// www.welt.de/politik/deutschland/article7036286/Deidesheimer-Hof-Kohls-zweites-Wohnzimmer.html>

77 Applegate, A Nation of Provincials.

78 Ibid., p. 246.

79 Bloch, E. 1959, Das Prinzip Hoffnung, Surhkamp, Frankfurt am Main, pp. 16, 28.
} 
community and the modern effects of the industrialised West by suggesting a conservative lifestyle that he associated with German culture ${ }^{80}$ In 1984, at the Tag der Heimat of the Federation of Expellees (BdV) in Brunswick, Kohl explained that

Heimat is a German word, which is not translatable into any other language. It makes us think of the compatriots and the landscape, the particularities of our language and our vernacular, of the social and cultural heritage, of history and stories, of tradition and custom, of many things that make life worth living and loving.

Heimat is the place or the country, where one is born and brought up or where one feels at home because of permanent residence [beheimatet ist]. To that belong people, like the family and the friends, the solidarity with neighbours and cohabitants, the familiarity with one's village, city, region, memories of the parental home, the school, and church. To that belong the commitments to values and the ancient ways of life of our Heimat.

Heimat derives from the term Heim [home], house and yard, from inheritance and property. Beyond the claim of ownership, however, Heimat first reminds us of the inalienable rights of every human to have a place he feels belonging to and where he finds security.

Heimat gives answers to the questions: Who am I, where do I come from, how did I become who I am...

Heimat thus means two things: the direct experience of a space and the spiritual relationship to anything that is distinct about that place. ${ }^{81}$

Remarkable in Kohl's rhetoric was that he would always try to guarantee the primacy of the West, which was more important to him than the recovery of Heimat in the territories Germany had lost in the East - even though the German Heimat was in his rhetoric always exclusively reserved for ethnic Germans and not for the non-ethnic German immigrants. ${ }^{82}$ This was not only in accordance with the perception of the West German mainstream, which was reluctant to

80 Kohl, H. 1986, 'Politik der Verständigung im Interesse des Friedens', [Speech delivered at the Tag der Heimat, Braunschweig, 2 September 1984], in Zur Teilung Deutschlands und Europa: Zusammenhänge, Perspektiven, Aufgaben, Europa Union, Bonn, pp. 51-70.

81 Ibid., pp. 52-4.

82 See, for example, Kohl, H. 1984, 'Koalition der Mitte: Für eine Politik der Erneuerung', [Policy statement to the Bundestag, 13 October 1982] in Reden 1982-1984, BPA, Bonn, p. 16, cf. pp. 25-6; Kohl, H. 1984, 'Bericht zur Lage der Nation im geteilten Deutschland', [Report to the Bundestag, 15 March 1984] in Reden 1982-1984, p. 222; Kohl, H. 1989, 'Deutsche Wiedervereinigung und Europa', [Speech delivered at the Bundestag, 1 December 1988] in Reden: Zu Fragen der Zukunft, BPA, Bonn, pp. 237-60, at p. 257; Kohl, H. 1991, Policy statement to the Bundestag, 30 January 1991, Plenarprotokoll 12/5; Kohl, H. 1991, Report as CDU Chairman to Federal Party Congress of the CDU, Dresden, 15 December 1991, <http://www.kas.de/upload/ACDP/CDU/ 
recognise that the FRG had been a country of mass immigration since the late nineteenth century, as Hans-Ulrich Wehler explained. ${ }^{83}$ It was also in line with Federal Republican legislation, which encouraged an ethnic and cultural notion of nationhood. ${ }^{84}$ Kohl's romantic image of nationhood was thus almost always contained within a socially, politically and legally acceptable context, which the politician carefully used in order to match the image of German normality.

\section{Kohl as Nationalist Historian}

Kohl can also be observed as a nationalist historian. Historians have traditionally played a vital role in the forging of nations. This problematic relationship between history writing and nationalism has received some well-deserved attention during the past decades. There has been a more self-reflective trend perceivable since the 1980s, when historians of nationalism, such as Benedict Anderson and Eric Hobsbawm in particular, pointed to the constructed nature, imagination and invention of national history. ${ }^{85}$ Yet the exploitation of historical material for nationalist purposes has not ceased. Nations cannot exist without the idea of a common national history, a fact that Kohl has been very much aware of, and prepared to take care of. For Kohl, 'a Volk cannot live without history...a Volk loses its identity when it denies its own history... One cannot remove oneself from the common history...He who does that removes himself from the solidarity of our Volk', as he asserted at the commemoration of the twentieth anniversary of the 1953 uprising in the GDR. ${ }^{86}$

The nation was to Kohl a fixed entity in the stream of modern history, and to save Germans from their allegedly ahistorical post-nationalism, he sought to exonerate Germans from the Nazi past by stressing positive continuities and by de-substantiating the memory of Nazism. ${ }^{87}$ As already mentioned, Kohl's PhD is a valuable document in that regard. In his thesis, Kohl was interested neither in explaining the causes of the Nazi era nor in what actually happened during

Protokolle_Parteitage/1991-12-15-17_Protokoll_02.Parteitag_Dresden.pdf> p. 34; Kohl, H. 1993, [Speech delivered at the Evangelische Arbeitskreis der CDU/CSU, Wittenberg, 29 September 1992], in Hintze and Langguth, Helmut Kohl, p. 426.

83 Wehler, H.-U. 2008, Deutsche Gesellschaftsgeschichte: 1949-1990. Volume V, C. H. Beck, Munich, p. 40.

84 For the relevant section in the Basic Law, see Jarausch, K. and Gransow, V. (eds) 1994, Uniting Germany: Documents and debates, 1944-1994, A. Brown and B. Cooper (trans), Berghahn, Oxford, p. 7; see also Gesetz über die Angelegenheiten der Vertriebenen und Flüchtlinge (Bundesvertriebenengesetz) [Federal Expellees Act] (Germany), 19 May 1953, BGBL I, 1953, 1902, art. 1 [hereinafter BVFG].

85 Anderson, B. 1991, Imagined Communities: Reflections on the origin and spread of nationalism, [second edn], Verso, London; Hobsbawm, E. and Ranger, T. (eds) 1992 [1983], The Invention of Tradition, Cambridge University Press, Cambridge.

86 Kohl, H. 1973, Der 17. Juni 1953. 20 Jahre Danach, Speech delivered at CDU/CSU event, BerlinCharlottenburg Sporthalle, 17 June 1973, Archive of the Konrad-Adenauer-Foundation, Kohl/2/293.

87 Moller, S. 1998, Die Entkonkretisierung der NS-Herrschaft in der Ära Kohl, Universität Hannover, Hannover. 
this time. His thesis aimed at the establishment of positive liberal continuities in German politics from the Kaiserreich, the Weimar Republic, via the Resistance during Nazi times to the political renewal of the Federal Republic. It was designed to contribute to the FRG's foundation myth, glorifying the foundation fathers and rehabilitating German history as such. Steven P. Remy, in his book about Kohl's alma mater, showed that those who had lost their positions under Nazi rule remained, with a few exceptions, effectively absent from the academia of the 1950s. ${ }^{88}$ Kohl's university education took place in an atmosphere of suppressing the past rather than coming to terms with it: his professors tried to justify their Nazi membership and the content of their former lectures and publications. In the curriculum vitae attached to Kohl's thesis, he mentioned six scholars at Heidelberg whom he saw as most influential for his study. ${ }^{89}$ Interestingly, among the six were four historians who had been affiliated in different ways with Nazi ideology: Walther P. Fuchs, Fritz Ernst, Johannes Kühn and Werner Conze. Kohl's instrumental and uncritical appropriation of history for ideological purposes is thus no great surprise. Already during his time as a university student, Kohl dedicated most of his time to politics, and there is no indication that he ever aimed at a career in academia; however, he saw it as part of his political role to engage with German history and intellectual debates: in the 1960s, Kohl began to publish newspaper articles in reaction to a collective culture of shame in Germany that he saw as a hindrance for Germans to find 'a lasting national self-image'.$^{90}$

With his chancellorship, Kohl became the most important voice within a wider conservative movement in West Germany, which sought to encourage Germans to walk out of Hitler's shadow. ${ }^{91}$ His initiative to build two museums of national history then caused increasing controversy and should be seen as part of the intellectual atmosphere surrounding the Historikerstreit. Kohl was predominantly accused of imposing an official history for nationalist purposes. ${ }^{92}$ What is sometimes overlooked in that regard, however, is that a key motivation in creating these museums was Kohl's constant battle over the prerogative to

88 Remy, S. 2002, The Heidelberg Myth: The Nazification and denazification of a German university, Harvard University Press, Cambridge, Mass.

89 Kohl, Die politische Entwicklung in der Pfalz und das Wiedererstehen der Parteien nach 1945. The CV is at the last page of his thesis.

90 Kohl, H. 1966, 'Angst vor der Geschichte?', Die Rheinpfalz, 7 May 1966; see also Kohl, H. 1968, 'Wie soll es nun weitergehen?', Die Rheinpfalz, 22 June 1968.

91 Evans, R. 1989, In Hitler's Shadow: West German historians and the attempt to escape the Nazi past, Pantheon Books, New York.

92 Kohl, H. 1984, 'Programm der Erneuerung: Freiheit, Mitmenschlichkeit, Verantwortung', [Policy statement at the Bundestag, 4 May 1983], in Reden 1982-1984, pp. 115-63, 159, 161-2. For a more detailed account of the debates surrounding the DHM, see Stölzl, C. (ed.) 1988, Deutsches Historisches Museum: Ideen, Kontroversen, Perspektiven, Propyläen, Berlin; and also Mälzer, M. 2005, Ausstellungsstück Nation: Die Debatte um die Gründung des Historischen Museums in Berlin, Friedrich-Ebert-Stifung, Bonn, <http://library.fes.de/ pdf-files/historiker/02952.pdf > For a critical account of Kohl's politics with the past, see also Moller, Die Entkonkretisierung der NS-Herrschaft in der Ära Kohl. 
interpret German history against his antagonists in East Berlin. He excluded the GDR from the appropriation of the Kulturnation, the cultural nation. He was thus worried not only that younger generations would have a different notion of Germany and the republic than he had, but also that the GDR would monopolise German history for its own purposes. The GDR and the division, on the contrary, were in Kohl's rhetoric artificial constructs, aberrations from the natural, normal and national course of history as much as the Third Reich had been. ${ }^{93}$

The anti-communist factor in Kohl's Geschichtspolitik should not be underestimated. Throughout his career, Kohl represented Germans themselves as victims of Nazism and communism. There are a number of noteworthy examples of this. ${ }^{94}$ One of Kohl's greatest scandals occurred in 1985, when he visited the Bitburg War Cemetery with US President, Ronald Reagan. ${ }^{95}$ It was insensitive to choose a cemetery where SS members were buried, yet the US President supported Kohl's quest for Germany to be a normal nation, even though the Bitburg scandal was counterproductive to this ambition as well as to Reagan's own political success. Nevertheless, Reagan backed the German Chancellor on West Germany's participation in the Strategic Defence Initiative. ${ }^{96}$ Reagan proclaimed that even the young SS soldiers in the cemetery were victims 'just as surely as the victims in the concentration camps'. ${ }^{97}$

\section{Conclusion}

Kohl's biography facilitates a better understanding of the contemporary history of German nationalism. He felt Germany's reputation, being held responsible for the two world wars and the Holocaust, was a thorn in his side. In order to overcome the Sonderweg paradigm, he thus sought to represent normal, Western continuities of the German nation that would prove the good essence of his people. His nationalism was fundamentally shaped by his early socialisation,

93 Kohl, ‘Der 17. Juni 1953. 20 Jahre Danach'; Kohl, H. 1980, Perspektiven deutscher Außenpolitik für die 80er Jahre, Speech delivered to the Wirtschaftstag '80, Frankfurt am Main, 18-19 July, Archive of the Konrad Adenauer Foundation, Kohl/Reden; Kohl, 'Bericht zur Lage der Nation im geteilten Deutschland'.

94 Kohl said this very clearly during a TV interview in The Hague in 1974; see BPA, ZDF, ‘Bürger FragenPolitiker Antworten', [Kohl interviewed in The Hague by Reinhart Appel], 22 February 1974, Archive of the Konrad Adenauer Foundation, Kohl/SII-2. He repeated the claim that the Weimar Republic had been destroyed by the common effort of communists and fascists in his first policy statement to the Bundestag: in Kohl, H. 1984, 'Koalition der Mitte: Für eine Politik der Erneuerung', [Policy statement to the Bundestag, 13 October 1982], in Reden 1982-1984, BPA, Bonn, pp. 9-49, at p. 47. Also, his comparison between Gorbachev and Goebbels was perceived as scandalous; see 'Kohl to Reagan: "Ron, be patient"', Newsweek, 27 October 1986.

95 Hartman, G. (ed.) 1986, Bitburg in Moral and Political Perspective, Indiana University Press, Bloomington.

96 'Re-enter Germany: SDI plus Bitburg equals new West German power?', The Economist, 10 May 1985.

97 Jensen, R. 2007, Reagan at Bergen-Belsen and Bitburg, Texas A \& M University Press, College Station, Tex., p. 62. 
such as the Catholic milieu, his belonging to the 45 generation, his teenage membership of the CDU, his regional background in the Rhine Palatinate, and his university education at Heidelberg in the 1950s. In accordance with these biographical features, Kohl's notion of the German nation was filled with elements of Catholicism, liberal and romantic nationalism, as well as components of historicism. The combination of these elements helped him to articulate a normal, Western nationalism within the context of the Cold War and its aftermath. Kohl used his biography to present himself as an ideal German, who was in his own eyes Christian, liberal and anti-communist, rooted in local traditions, conscious of Germany's glorious past and free from any Nazi guilt. He tried to represent a departure from the new and the old Sonderweg, a proud German about whom nobody had to worry anymore. He has been the paragon of Germany's new normality. 